\section{First European experiment}

\section{Munich}

A TEAM of Italian researchers is expected to receive permission for the first human gene therapy experiment in Europe before the end of the year, setting the stage for further experiments in other countries.

Claudio Bordignon of the Istituto Scientifico San Raffaele in Milan is the leader of the team and was an associate of the group that last July won approval for a similar experiment from the Recombinant DNA Advisory Committee (RAC) of the US National Institutes of Health $(\mathrm{NIH}$; see Nature 346, 402; 1990). Bordignon says that there are groups in the Netherlands and France that will soon be ready to perform gene therapy experiments.

There has been an outcry against the experiment in Italy, because of fears that unscrupulous researchers may visit Italy to perform experiments on humans. A group of parliamentarians asked the Health Ministry for a moratorium on gene therapies, especially germ-line therapy. But Francesco de Lorenzo, the Health Minister, says that it is up to the hospital in question to decide if the experiment meets medical and ethical standards.

Bordignon expects speedy approval for the experiment because his protocol is more conservative than that approved by $\mathrm{RAC}$ in the United States. He is treating a three-year-old child for a rare inherited immune disorder caused by a deficiency of the enzyme adenosine deaminase (ADA). The deficiency causes an almost complete absence of normal immune function, meaning that children who suffer from it - there are fewer than 20 worldwide must live in a sterile 'bubble' unless the enzyme can be replaced.

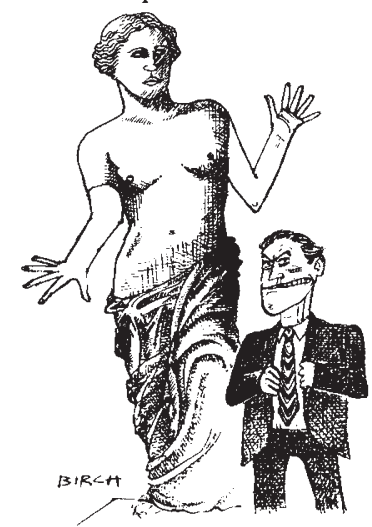

Bordignon intends to remove some of the child's T lymphocytes and insert a normal human ADA gene into them. But the altered T-cells will be put back into the child's body only if current treatment with bovine enzyme fails. Until that time, the altered $T$ cells will be frozen.

Unlike the United States, European countries have so far viewed somatic gene therapy as just another medical treatment that does not present special moral or ethi- cal problems. There is no equivalent to RAC in Italy or many other European countries. Nevertheless, opposition to genetic engineering may make such experiments difficult in countries such as Germany. Peter Lange, head of the section for basic questions in biology and health at the German Research and Technology Ministry says that "as soon as the press finds out about this [in Germany], there will be a huge discussion. It has been so quiet so far", he adds, "only because the public does not realize how close [the experiments] are to reality."

The EC consensus, reiterated at a March 1990 meeting of research ministers at Kronberg in Germany, breaks down when it comes to germ-line gene therapies. Although the ministers agreed to reject germ-line therapies for the moment, says Lange, their opinions diverged about whether such therapies will be permitted in their countries in the future. Changing the germ line using genetic engineering will become illegal in Ger-

\section{Budapest}

ACADEMIC computer users in Eastern Europe will be the among the first to benefit as foreign manufacturers rush to fill the vacuum in the market for computers. Following a pattern set in the early 1980 s in North America and Western Europe, IBM and other companies are offering their equipment to universities at little or no cost in the hope of persuading a generation of students and professors of the value of their products.

The scientific community sees the computer technology as essential to raising its standards. "We hope we can catch up ten years in just two or three years using these new computers", says Alexander Szalay, an astrophysicist and network manager at Loránd Eötvös University in Budapest.

The most ambitious project so far is the Academic Computer Initiative of IBM Europe under which it is installing mainframe computers (the largest computers ever installed in the region) in Czechoslovakia, Hungary, Yugoslavia and Poland. The countries will then be linked to the West through the Vienna node of the European Academic Research Network.

On 20 November, IBM signed a cooperative agreement with three universities in Budapest under which the company will provide a mainframe computer and Hungary's first-ever fibre optic network.

The Budapest and Belgrade computers will be installed next spring, says Judit many at the beginning of next year.

The EC Commission is setting up a committee to look into the ethical and social implications of human genome analysis (which may also deal with gene therapies) but an EC official in Brussels says that it is up to the member states to regulate the therapies at a national level. In the official's opinion, any attempts to ban somatic gene therapy throughout the EC might well fail because of Article 36 of the Treaty of Rome, which allows nations to deviate from Community policy with respect to issues of "public morality . public safety and the protection of human life and health".

The EC official also fears the effect of press coverage on this field of research in Europe. The official says that "merely drawing attention to this situation creates what looks like a legislative vacuum . . that politicians will rush to fill", with the consequence that an inflexible bureaucracy would be created "with an interest in self-perpetuation". It would be far better, says the official, to let researchers themselves advise the EC how to proceed in such a fast-moving field.

Steven Dickman

\title{
Eastern Europe comes online
}

Quittner of IBM Hungary. Earlier this month another computer of the same model, a 3090-120, was installed in Prague. At the same time, Digital Equipment Corporation (DEC) is about to sign an agreement with Eötvös University to install, at large discounts, both hardware and software for electronic mail within the university and, eventually, among several universities in Hungary.

According to George Balatoni of DEC Hungary, the size of the potential Eastern European market should not be underestimated. Balatoni estimates DEC will sell $\$ 100$ to $\$ 150$ million of equipment in Eastern Europe in the next five years, beginning with Hungary, the only country so far where DEC has established a majority-owned subsidiary.

Obtaining both IBM and DEC products at the same time is an especially useful combination for researchers in Hungary, says Szalay. Until now, owing in part to Western high-technology export restrictions, the most advanced computers in the country were microcomputers. IBM will fill a gap with its large computers, while the DEC systems will be able to connect systems of many different manufacturers, including IBM and Apple.

Szalay praised both companies for "listening to our needs" and helping Hungary to choose not the latest technology but rather the most cost-effective system that it will be able to afford to expand.

Steven Dickman 